\title{
Journal of Management and Marketing Review
}

\section{Human Capital and Social Capital as Moderators of Start-up Support and Start-up Success}

\author{
Daisy Mui Hung Kee, ${ }^{1} *$ Sabai Khin ${ }^{2}$
}

${ }^{1,2}$ School of Management, Universiti Sains Malaysia, 11800, Penang, Malaysia

\begin{abstract}
Objective - Start-up support has not received enough research attention although it is an integral element of the start-up ecosystem that provides resources and services in the form of various support to start-ups. There is a need to explore the effectiveness of various start-up support because the question as to whether such supports contribute to start-up success remains unanswered.

Methodology/Technique - While human capital and social capital has been linked to entrepreneurial success, little is known about how these capitals moderate the effect of start-up access to support.

Findings - This paper contributes to start-up literature by presenting a conceptual framework appropriate to investigate the effect of a start-up's access to support on start-up success as well as how this effect is accentuated by the human and social capital of start-up entrepreneurs.

Novelty - Further understanding of how human capital and social capital could strengthen the contribution of support to start-up success represents an important direction for future entrepreneurship research. This paper also discusses the limitations of relevant previous research and offers suggestions for future research.
\end{abstract}

Type of Paper: Review.

Keywords: Start-up Support; Start-up Success; Human Capital; Social Capital; Malaysia.

Reference to this paper should be made as follows: Kee, D. M. H.; Khin, S. (2019). Human Capital and Social Capital as Moderators of Start-up Support and Start-up Success, J. Mgt. Mkt. Review, 4 (2): $107 \quad-114$ https://doi.org/10.35609/jmmr.2019.4.2(2)

JEL Classification: M10, M13, M19.

\section{Introduction}

Previous literature on entrepreneurship has witnessed the importance of the entrepreneurial ecosystem to the success of a start-up. Every nation needs to create a supportive ecosystem to nurture entrepreneurs and help them grow a start-up that would fuel the economy and create employment. Entrepreneurial support as part of the entrepreneurial ecosystem is essential because start-ups require the right mix of capital and resources to succeed, in the absence of which they often look for external guidance and assistance (Yusof, 2010).

* Paper Info: Revised: March 11, 2019

Accepted: June 18, 2019

* Corresponding author: Daisy Mui Hung Kee

E-mail: daisy@usm.my

Affiliation: School of Management, Universiti Sains Malaysia, Malaysia 
Isenberg (2011) has identified six domains within the entrepreneurial ecosystem: a conducive culture, enabling policies and leadership, availability of appropriate finance, quality human capital, venture friendly markets for products, and a range of institutional supports. Among these six domains, institutional support has not received deserving attention from academic researchers. In entrepreneurship literature, entrepreneurial support could be found as institutional support that would enable young entrepreneurs to develop their business ventures by endowing them with the resources necessary for a successful venture. Support takes many forms such as mentoring programs, incubation facilities, research support for products or technology, and financial support such as funding, loans, venture capitals and so on. Many government or private institutions provide support to start-ups by providing finance-related support, advice in the form of coaching, mentoring, and training, professional assistance, acceleration programs and sharing sessions by successful entrepreneurs. Yusof (2014) suggests that an evaluation of the impact of assistance/support programs is an important contribution to the practice of, and research on, entrepreneurship policy.

Based on the collective findings in the context of 10 countries, Henry and Treanor (2013) point out that current support for new venture creation continues to be under-utilized, under-evaluated and not entirely aligned to the needs of aspiring and existing new ventures and calls for academics to be involved in objectively evaluating the effectiveness of existing initiatives. Hence, this paper heeds that call by providing on understanding of the contribution of start-up support initiatives to start-up success.

Although a significant body of research has been conducted to understand the factors contributing to the success of new ventures, the role of entrepreneurial support in start-up success is yet to receive deserving attention in the research arena of a new venture or start-up success. One of the reasons for this is that entrepreneurial ecosystems have gained increased focus by authorities of many countries around the world in recent times. Many countries have begun to establish institutions or agencies to support start-ups that are believed to boost the economy. Along with increased attention to nascent entrepreneurs and start-ups, the availability of funding, improved infrastructure and start-up ecosystems, the development of start-ups has become easier in many countries.

However, start-up entrepreneurs face many challenges in developing successful ventures despite the availability of support and better ecosystems. Some of them find that it is not easy to access to support or fail to get support due to limited resources in some countries. They face key challenges and obstacles such as lack of awareness in terms of resources, lack of information in terms of business opportunities, inadequate networking, and absence of business support (Aggarwal, 2012; Kee, Effendi, Talib \& Rani, 2011). Ng and Kee (2017) state that most SMEs often struggle to keep on top of new development and encounter problems in their operation to the point that governments are required to intervene in SME development by providing infrastructure and financial grants. Kee et. al. (2011) found that most SMEs rely on private sponsors or selffunding to obtain financial support, penetrate new markets and search for customers as they did not receive the full range of assistance due to the complicated procedure of finance applications.

In some cases, support in terms of training or advisory services does not seem to be effective or mismatched with the needs of its users. There are still many other reasons for not making the most of available support, and the contribution of accessible support to the performance of start-ups is still underexplored. This prompts the research question: "To what extent does start-up support contribute to startup success?" It is essential to understand the real impact of supporting institutions because authorities need to ensure that all start-up entrepreneurs have equal access to, and make the best use of, available support and resources so as not to waste the effort of building up the supportive start-up ecosystem. Therefore, this study presents a conceptual framework which to ascertain the effect of start-up support on start-up success.

In addition to the contribution of start-up support to success, little is known about whether this contribution is subject to other factors such as human capital and social capital of start-up entrepreneurs. From both a management and policy perspective, it is necessary to study human capital, as this is a crucial factor in the relationship between individual capabilities and new venture outcomes (Cleyn, Braet \& 
Klofsten, 2015). Due to the lack of available research on human capital and social capital in the context of support and start-up success, it is still questionable whether human capital and social capital could strengthen the contribution of support on start-up success. This paves the way for the second research question in this paper -"Does the effect of start-up support and start-up success depend on start-up entrepreneurs' human and social capital?"

Unger, Rauch, Frese, and Rosenbusch (2011) suggest that human capital increases an owners' capabilities of discovering and exploiting business opportunities and helps them acquire other resources such as financial and physical capital, whilst assisting in the accumulation of new knowledge and skills. It is possible that the entrepreneur's human capital, such as their skills, knowledge, and experience, enable them to make the best use of available support. For example, an entrepreneur with prior experience in commercializing similar products that he is venturing into may have a better idea of what kind of support they need to develop the product and how to go about it. Moreover, if the entrepreneur has education and knowledge to develop that product, it is easier for him to obtain assistance from, or collaborate with, relevant research institutions that assist with product development and commercialization. Those relevant skills would also enable them to make the best use of available resources and support in developing their business. Therefore, it is important to examine the moderating effect of human capital on the relationship between start-up support and start-up success to understand whether human capital could accentuate the effect of start-up support on start-up success.

Apart from entrepreneurs' human capital, entrepreneurs' social capital, which is the network of relationship with friends, family, other entrepreneurs and stakeholders is also essential for their success as it provides the relationships through which an entrepreneur receives opportunities for business support and resources such as information, advice, and even financial help. To date, the research interest in social capital is growing, and most of the studies in entrepreneurship conclude that social capital is related to success (e.g., Stam et. al., 2014; Ding \& Abetti, 2003). However, there is some inconsistency in the research findings with respect to which dimensions of social capital are relevant and whether they directly or indirectly impact success. Moreover, most previous studies have tested the direct relationship of social capital and human capital with venture success, leaving a gap in the literature to examine its indirect effect on success, particularly in the context of start-up firms. Therefore, there is a critical need to investigate the indirect effect of human and social capital on start-up success, such as the moderating effect, to understand whether human capital and social capital could enhance the contribution of supporting services to start-up success.

The main objective of this paper is to advance a new conceptual framework that is appropriate for future researchers to investigate the effect of entrepreneurs' access to start-up support on their success, and the moderating effect of human capital and social capital on the relationship between start-up support and startup success. Theoretically, this study contributes to the literature by proposing a conceptual framework that could potentially contribute to the development of a new research agenda geared towards assessing the contribution of start-up support through the lens of the human and social capital factors of entrepreneurs. Practically, this study contributes to start-up entrepreneurs by highlighting the need to gain access to start-up support and to take account of their human and social capitals in an endeavor to develop a successful start-up. In addition, the proposed framework may draw the attention of policy makers and authorities to the start-up ecosystem towards developing human and social capital of young entrepreneurs while implementing initiatives for supporting and nurturing start-ups.

\section{Literature Review}

\subsection{Start-up Support and Start-up Success}

Research considering start-up support and its impact on start-up success is in its infancy. There is still a need for more research that recognizes the importance of entrepreneurial support to new venture success. To date, a few studies were found to have investigated the impact of start-up supports in relation to venture 
success (e.g. Yusuf, 2014; Deakins et. al, 1998; Delanoe, 2013; Brüderl \& Preisendörfer, 1998), while some studies have examined the impact of effectiveness of entrepreneurial assistance programs (e.g. Chrisman et. al., 2005; Chrisman \& McMullan, 2000; Nahavandi \& Chesteen, 1988). A study by Delanoe (2013) reveals a positive link between professional support and start-up outcomes. Likewise, Jansen and Weber (2004) cite evidence from Germany that public advice and training programs for entrepreneurs have, in general, had a positive effect on the success of new firms. Among the various supports available, more research attention is given to specific supports such as financial support, training support, technological support, mentoring support, and business support. Therefore, there is still room for researchers to look at all aspects of support that start-up needs. This study aims to fill this gap by conceptualizing four areas of support: marketing, technology, finance and education, which are the key areas of support that the government provides based on research by Heydebreck et. al. (2002).

In addition to focusing on the impact of support on success, some studies examine the differentiating factors, such as age, in gaining access to support. An interesting study by Pickernell et. al. (2013) reveals that new and young firms are better able to access beneficial resources in terms of finance and advice from several sources as well as the government, but less able to access public procurement. In addition to age, entrepreneurs' working experience, knowledge, skills, education and their social networks could accentuate the contribution of start-up support on start-up success. To the best of our knowledge, no study has tested the moderating effect of human capital and social capital on the effect of support on start-up success. Therefore, this study fills this research gap by positing that human capital and social capital are moderators of the link between support and success.

\subsection{Human Capital}

Human capital was first introduced by Gary Becker (1964). The "capital" is multidimensional in the economics literature in the 21st century, and it has been extended to include such terms as financial capital, organizational capital, human capital, intellectual capital, relational capital and social capital (Edvinsson \& Malone, 1997). Human capital such as the skills, knowledge, and experience possessed by an individual has been empirically proven to have a positive impact on the survival of a new venture, profitability, and growth (Dobbs \& Hamilton, 2007; Jones et. al., 2010). For example, a qualitative study of entrepreneurs in Ghana carried out by Adom and Asare-Yeboa (2016) reveals that one's level of education, business training and knowledge gained during their work were crucial factors for their entrepreneurial success.

The World Bank Group has recently unveiled a new system to rank countries based on their success in developing human capital. The World Bank Human Capital Index shows that out of 157 economies, Singapore ranks first in the human capital ranking, followed by South Korea, Japan and Hong Kong (The Straits Times, 11 October 2018). In an entrepreneurial context, human capital refers to the skills, experience and education of an entrepreneur (Becker, 1964). Although researchers have agreed that human capital, in general, has a positive contribution towards the success of a new venture, some researchers have found empirical evidence of a positive effect of human capital elements such as education, knowledge, or skill but not all elements in one study. Therefore, the present paper looks at four elements of social capital (education, knowledge, experience, and skills) to understand how the elements interact with the support-success relationship.

Although most authors conclude that human capital is related to venture success (e.g., Bosma et. al., 2004; Van der Sluis et. al., 2005), some authors do not find empirical support. For example, Hitt et. al. (2001) found no support for their one test of the interaction of human capital and leveraging capabilities on firm performance. Moreover, Unger et. al. (2011) points out that although a positive relationship between human capital variables and success is well established, uncertainty remains over the magnitude of this relationship as well as the circumstances under which human capital is strongly associated with success. They also point out that it remains unclear what kind of human capital should be related to success and under what circumstances, commenting that no study has systematically investigated the moderators influencing the 
human capital - success relationship. These literature findings prompt a need to explore whether human capital could be an important moderator in the support-success relationship. Therefore, the present paper advances a conceptual framework that can be used to examine the non-static effect of human capital and social capital as moderators of the start-up support-start-up success relationship.

\subsection{Social Capital}

Social capital is the ability of actors to secure benefits by membership in social networks or other social structures (Portes, 1998). When entrepreneurs face resource constraints or need help, they often look to their friends and family members to gain access to the resources and support they need. Therefore, social capital, such as personal networks, is a critical factor in gaining accesses to both tangible and intangible resources, support, and business opportunities that they might not have direct access to. Social capital encompasses family members, social networks, connections, etc. that may provide useful resources for new business ventures (Baron \& Markman, 2000). Anklam (2002) suggests that social capital encompasses the context, stock of relationships, interpersonal trust and norms that allow certain behaviors and relationships between individuals, and that ensure conditions for the development of organizations and knowledge sharing.

Social capital has also been recognized as the source of resources and information. Xie and Lv (2016) suggest that technology entrepreneurs can access knowledge, information, and funds through social networks. Neira et. al. (2017) reveal that social networks, as a measure of the individual's social capital, are positively and significantly related to the early-stages of entrepreneurship. Likewise, Larson and Starr (1993) point out that entrepreneurs often use their social capital to gain resources in the beginning stages of a new venture, at which point the social capital possessed by their new ventures is virtually identical to that possessed by the firm's founder. This means that an entrepreneur's network becomes their business network in gaining access to resources that their start-up venture requires.

Some studies conceptualized social network and social skills from the perspective of social capital theory which refers to the ability of individuals to extract benefits from their social structure, interpersonal relationships and their membership in social organizations (Lin et. al., 1981). Social theory has been used to explain entrepreneurs' social networks and social skills to maintain a good relationship with people as key factors for entrepreneurial growth. Researchers have positively linked social capital to start-up success using social capital theory. For example, Xie and Lv (2016) report that the social networks of female techentrepreneurs have a significant positive impact on new venture performance. Although numerous studies have identified the positive impact of social capital on venture success, Afandi et, al. (2016) points out that there is an absence of unanimously used dimensions of social capital. They use three dimensions: trust, network and norms. Although social network has been widely used as a determinant of entrepreneurial success, social skill have not been tested empirically, particularly in the context of start-up success. Baron and Markman (2000) state that entrepreneurs' social skills - specific competencies that help them interact effectively with others - may also play a role in their success. Social skill are an important dimension of social capital in the entrepreneurial context because without it, entrepreneurs cannot develop, sustain, and increase their business network.

Since social capital is considered an activity with multiple dimensions (Wide'n-Wulff \& Ginman, 2004), there is still room for researchers to examine the different effects of its various dimensions. Further, most previous studies have tested the direct effect of social capital and little research has examined how social networks of start-up entrepreneurs interact with other factors such as start-up support in start-up success literature. This literature gap sheds light on the need to explore its moderating effect, particularly in relation to the entrepreneurial ecosystem and support. Therefore, this study explores the moderating effect of social capital on the relationship between start-up support and success. Two dimensions of social capital, social network and social skills, are used to understand how the start-up entrepreneurs' social network with their friends and family and their ability to interact effectively with others are best used to optimize the benefits of accessible support to develop a successful start-up. 


\section{Research Methodology}

This paper is a conceptual paper based on the review and analysis of research from the literature related to start-ups in Malaysia. This paper will mainly focus on the practical experiences of start-up owners. The owners will be asked about the success of their start-up and how the support (finance, technology, market and soft-related support) helped in their start-up success. They will be asked to provide their opinions regarding the roles of social capital and human capital. The questionnaire will be used to assess 500 start-ups that are also the recipients of support/funding from various agencies in Malaysia.

\section{Results and Findings}

Henry and Treanor (2013) suggest that current support for new venture creation continues to be underutilised, under-evaluated and not entirely aligned to the needs of aspiring and existing new ventures. Therefore, there is a critical need to investigate the impact of entrepreneurial support in relation to start-up success to understand its effectiveness and whether it meets the needs of a start-up. It is believed that firms with abundant resources can survive and grow as compared to those having a scarcity of resources and can pursue their goals more efficiently (Farooq, 2017). Therefore, the following research propositions are proposed.

1. Proposition 1: Start-up entrepreneurs' access to finance-related support has a positive effect on start-up success.

2. Proposition 2: Start-up entrepreneurs' access to market-related support has a positive effect on start-up success.

3. Proposition 3: Start-up entrepreneurs' access to technology-related support has a positive effect on start-up success.

4. Proposition 4: Start-up entrepreneurs' access to soft-related support has a positive effect on startup success.

5. Proposition 5: The education level of start-up entrepreneur enhances the effect of start-up support on start-up success.

6. Proposition 6: The experience level of start-up entrepreneur enhances the effect of start-up support on start-up success.

7. Proposition 7: The knowledge level of start-up entrepreneur enhances the effect of start-up support on start-up success.

8. Proposition 8: The skill levels of start-up entrepreneur enhances the effect of start-up support on start-up success.

9. Proposition 9: social networks of start-up entrepreneur enhances the effect of start-up support on start-up success.

10. Proposition 10: The social skills of start-up entrepreneur enhances the effect of start-up support on start-up success.

\section{Discussion and Conclusion}

The body of knowledge surrounding start-up success is still evolving with more and more new factors emerging as antecedents of start-up success. Start-up support is an important factor that calls for more empirical research. Numerous studies suggest linking entrepreneurial support to start-up success in an attempt to enhance economic growth. This study expands this idea by proposing that entrepreneurs who have access to support can develop successful start-ups and that both human capital and social capital can enhance the contribution of support on start-up success. 
This paper makes several contributions to the existing body of knowledge on start-up success. Firstly, it adds a new conceptual model of start-up success that links both external factors (start-up support from institutions) as antecedent and internal factors (human and social capital) as moderators. These moderators may explain some of the contradictory findings in support-success literature. Secondly, the current study can be viewed as the first to identify the moderating role of human and social capital on the support-success link. Furthering the understanding of how human and social capital can be used to strengthen the contribution of start-up support to start-up success represents an important direction for future entrepreneurship research.

Thirdly, the proposed factors may draw more attention of start-up entrepreneurs to improve the human and social capital that would enable them to make the best use of available support and resources. Fourthly, the proposed model can be used as an analytical tool by start-up firms and nascent entrepreneurs to gauge their success as well as policymakers in selectively funding entrepreneurs with a good level of human and social capital. Further, the findings will assist governments across the globe to evaluate the programs and initiatives currently available to start-ups.

\section{Acknowledgements}

This research is supported by a mini social research grant from the Malaysian Technology Development Corporation.

\section{References}

Adom, K. and Asare-Yeboa, I. T. (2016). An Evaluation of Human Capital Theory and Female Entrepreneurship in Sub-Sahara Africa: Some Evidence from Ghana. International Journal of Gender and Entrepreneurship, 8(4), 402-423. https://doi.org/10.1108/IJGE-12-2015-0048

Afandi, E., Kermani, M. and Mammadov, F. (2017). Social Capital and Entrepreneurial Process. International Entrepreneurship and Management Journal, 13, 685-716. DOI: 10.1007/s11365-016-0421-8

Anklam, P. (2002). Knowledge Management: The Collaboration Thread". Bulletin of the American Society for Information Science and Technology, 28(6), 1-8 https://doi.org/10.1002/bult.254

Aggarwal, R. (2012). Research on the State of Business Incubation System in Rwanda: Lesson for African Countries. $\begin{array}{lllll}\text { Journal of } & \text { US-China } & \text { Public } & \text { Administration, } & 97 \text { (6), }\end{array}$ https://papers.ssrn.com/sol3/papers.cfm?abstract_id=2465371\#page=112

Baron, R. A., \& Markman, G. D. (2000). Beyond Social Capital: How Social Skills Can Enhance Entrepreneurs' Success. Academy of Management Executive, 106-116. Becker, G. (1964). Human Capital. New York: Columbia University Press. https://doi.org/10.5465/ame.2000.2909843

Bosma, N., Praag, M. V., Thurik, R., \& Wit, G. d. (2004). The Value of Human and Social Capital Investments for the Business Performance of Start-up. Small Business Economics (23), 227-236. http://ondernemerschap.panteia.nl/pdfez/n200204.pdf

Bosma, N. S., \& Levie, J. (2010). Global Entrepreneurship Monitor 2009 Executive Report. https://dspace.library.uu.nl/handle/1874/209570

Chrisman, J. J., McMullan, E., \& Hall, J. (2005). The influence of guided preparation on the long-term performance of new ventures. Journal of Business Venturing, 20(6), 769-791. https://doi.org/10.1016/j.jbusvent.2004.10.001

Chrisman, J. J., \& McMullan, W. E. (2000). A preliminary assessment of outsider assistance as a knowledge resource: the longer-term impact of new venture counselling. Entrepreneurship Theory and Practice, 24(3), 39-53. https://doi.org/10.1177/104225870002400303

Cleyn, S. H. D., Braet, J., \& Klofsten, M. (2015). How human capital interacts with the early development of academic spin-offs. International Entrepreneurship and Management Journal, 11(3), 599-621. DOI:10.1007/s11365-013-0294-z

Deakins, D., Graham, L., Sullivan, R., \& Geoff, W. (1998). New venture support: an analysis of mentoring support for new and early-stage entrepreneurs. Journal of Small Business and Enterprise Development, 5(2), 151 - 161. https://doi.org/10.1108/EUM0000000006763

Delanoë, S. (2013). From intention to start-up: the effect of professional support. Journal of Small Business and Enterprise Development, 20(2), 383-398. https://doi.org/10.1108/14626001311326789 
Ding, H.-b., \& Abetti, P. A. (2003). The entrepreneurial success of Taiwan: Synergy between technology, social capital and institutional support In G. D. Libecap (Ed.), Issues in Entrepreneurship (pp. 91-123): Emerald Group Publishing Limited. https://www.emeraldinsight.com/doi/abs/10.1016/S1048-4736(02)14005-7

Dobbs, M., \& Hamilton, R. T. (2007). Small business growth: recent evidence and new directions International Journal of Entrepreneurial Behaviour and Research, 13(5), 296-322. https://doi.org/10.1108/13552550710780885

Edvinsson, L., \& Malone, M. S. (1997). Intellectual Capital. London: Piatkus. https:/www.coursehero.com/file/p56eoedo/Edvinsson-L-and-Malone-MS-1997-Intellectual-Capital-London-Piatkus-

Edvinsson-L/

Farooq, R. (2017). A conceptual model of frugal innovation: is environmental munificence a missing link? International Journal of Innovation Science, 9(4), 320-334. https://doi.org/10.1108/IJIS-08-2017-0076

Florin, J., Lubatkin, M., \& Schulze, W. (2003). A social capital model of high growth ventures. Academy of Management Journal, 46(3), 374-384. https://doi.org/10.5465/30040630

Henry, C., \& Treanor, L. (2013). Where to now? New directions in supporting new venture creation. Journal of Small Business and Enterprise Development, 20(2), 249-257. https://doi.org/10.1108/14626001311326824

Heydebreck, P., Klofsten, M., \& Maier, J. (2012). Innovation support for new technology-based firms: the Swedish Teknopol approach. R\&D Management, 30(1), 89-100. https://doi.org/10.1111/1467-9310.00160

Hitt, M., Bierman, L., Shimizu, K., \& Kochhar, R. (2001). Direct and moderating effects of human capital on strategy and performance in professional service firms: a resource-based perspective. Academy of Management Journal, 44(1), 13 - 28. DOI: 10.2307/3069334

Isenberg, D. (2011). Introducing the entrepreneurship ecosystem: Four defining characteristics. Forbes, May, 25,2011 https://www.forbes.com/sites/danisenberg/2011/05/25/introducing-the-entrepreneurship-ecosystem-four-definingcharacteristics/\#1cd3bbe35fe8

Jansen, D. (2004). Helping hands and entrepreneurship-supporting newly founded firms. Advances in interdisciplinary European entrepreneurship research, 57-79 https://papers.ssrn.com/sol3/papers.cfm?abstract_id=1497293

Hung, D. K. M., Effendi, A. A., Talib, L. S. A., \& Rani, N. A. A. (2011). A preliminary study of top SMEs in Malaysia: Key success factor vs government support program. Journal of global business and economics, 2(1), 48-58 https://ideas.repec.org/a/grg/01biss/v2y2011i1p48-58.html

Ng, H.S., \& Kee D.M.H. (2017). Entrepreneurial SMEs surviving in the era of globalization: Critical success factors. In. S. Sindakis, \& P. Theodorou (Eds.). Global Opportunities for Entrepreneurial Growth: Competition and Knowledge Dynamics within and across Firms, (pp. 75-90) Emerald Publishing Limited. 